\title{
A terminally modified pseudopeptide (Gly-m-aminobenzoic acid) produces supramolecular helix, staircase and water-mediated $\beta$ - sheet through self-assembly
}

\author{
Arpita Dutta, ${ }^{a}$ Sudeshna Kar, ${ }^{a}$ Roland Fröhlich, ${ }^{b}$ Pradyot Koley, ${ }^{a}$ and Animesh \\ Pramanik*a $^{a}$ \\ ${ }^{a}$ Department of Chemistry, University of Calcutta, 92, A. P. C. Road, Kolkata-700 009, India \\ ${ }^{b}$ Organisch-Chemisches Institut, Universität Münster, Corrensstraße 40, D-48149, Münster, \\ Germany \\ E-mail: animesh in2001@yahoo.co.in
}

\begin{abstract}
The pseudopeptide Gly- $m$-ABA ( $m$-ABA $=m$-amino benzoic acid) has been chosen to study the formation of supramolecular structures through self-assembly. Single crystal X-ray diffraction studies reveal that the pseudopeptide Boc-Gly-m-ABA-OMe (1), where both $\mathrm{N}$ - and C-terminus are protected, self-assembles to a supramolecular helical structure, whereas the pseudopeptide Boc-Gly-m-ABA-OH (2) with free $-\mathrm{CO}_{2} \mathrm{H}$ at the $\mathrm{C}$-terminus produces molecular staircase through self-assembly. Again the terminally unprotected pseudopeptide ${ }^{+} \mathrm{NH}_{3}-\mathrm{Gly}-m-\mathrm{ABA}-\mathrm{CO}_{2}{ }^{-}$ (3) aggregates to a water mediated supramolecular $\beta$-sheet structure stabilized by intermolecular hydrogen bonds and $\pi-\pi$ interactions. The study reveals that the terminally modified Gly- $m$-ABA generates various kinds of self-assembling building blocks that can fabricate different types of supramolecular architectures such as helix, $\beta$-sheet and staircase.
\end{abstract}

Keywords: Pseudopeptide, supramolecular helix, staircase, $\beta$-sheet, self-assembly

\section{Introduction}

In nature various biological systems such as rigid biomineralized shells and bones, ${ }^{1}$ high-strength spider silks, ${ }^{2}$ tobacco mosaic virus (TMV), ${ }^{3}$ collagen triple helix ${ }^{4}$ and DNA double helix ${ }^{5}$ are the results of molecular self-assembly. The design and synthesis of suitable molecular building blocks that can act as potential subunits for desired supramolecular architectures is an active area of current research. Creation of supramolecular helices ${ }^{6}$ and $\beta$-sheets ${ }^{7}$ through the self-assembly of small peptide building blocks have attracted considerable attention in the recent time because of their biological importance in various neurodegenerative diseases such as Alzheimer's disease, ${ }^{8}$ Huntington's disease, ${ }^{9}$ and prion-protein ${ }^{10}$. Moreover it has been observed that 
fabrication of various peptide based nanomaterials such as nanotubes, ${ }^{11}$ nanorods, ${ }^{12}$ and nanowires ${ }^{13}$ can be achieved through molecular self-assembly.

Therefore developing easily modifiable molecular scaffolds that will self-assemble to various supramolecular structures is important. In this context we chose a pseudopeptide Gly-m-ABA ( $m$-ABA $=m$-amino benzoic acid) which on modification at the terminal groups gives different self-assembling peptides such as Boc-Gly-m-ABA-OMe (1), Boc-Gly-m-ABA-OH (2) and ${ }^{+} \mathrm{NH}_{3}$-Gly-m-ABA-CO ${ }_{2}^{-}$(3) (Figure 1). In 1 both $\mathrm{N}$ - and $\mathrm{C}$-terminus are protected, whereas in 2 only $\mathrm{N}$ terminus is protected and in 3 both $\mathrm{N}$ - and $\mathrm{C}$-terminus are free. The incorporation of $m$ aminobenzoic acid in 1-3 may help in self-assembly through $\pi$-stacking interactions. Moreover $m$-aminobenzoic acid which is considered as a substituted $\gamma$-amino butyric acid with an all trans extended configuration is expected to provide extended and semi-extended structure in the backbone of the pseudopeptides. It will be interesting to know how the modification of the terminal groups in the pseudopeptide influences the self-assembly in the solid state. The result will provide insights for engineering supramolecular architectures in crystal. The pseudopeptides 1-3 were synthesized by conventional solution phase methodology and their crystal structures were obtained by X-ray diffraction studies.

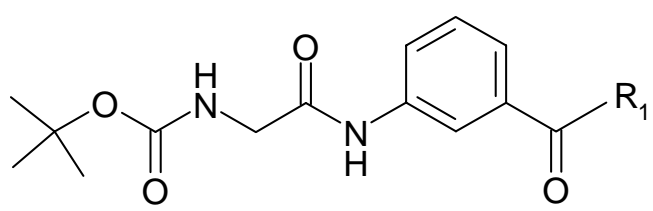

Pseudopeptide 1: $\mathrm{R}_{1}=-\mathrm{OCH}_{3}$

Pseudopeptide 2: $\mathrm{R}_{1}=-\mathrm{OH}$<smiles>[NH3+]CC(=O)Nc1cccc(C(=O)[O-])c1</smiles>

Pseudopeptide 3

Figure 1. Schematic diagram of pseudopeptides 1-3.

\section{Results and Discussion}

The colorless orthorhombic crystals of pseudopeptide $\mathbf{1}$ were obtained from chloroformpetroleum ether mixture by slow evaporation. Pseudopeptide 1 crystallizes with two molecules in the unit cell designated as $\mathbf{1 A}$ and 1B. The SCHAKAL diagram of one of the isomers of $\mathbf{1}$ with atom numbering scheme is presented in Figure 2. The $\phi, \psi$ values of Gly in $\mathbf{1 A}$ are $62.6^{\circ}$ and $130.6^{\circ}$ and that of in $\mathbf{1 B}$ are $-65.2^{\circ}$ and $138.0^{\circ}$, respectively (Table 1). Therefore $\mathbf{1 A}$ and $\mathbf{1 B}$ are two enantiomeric structures with a bend around Gly residue. In the unit cell the isomers $\mathbf{1 A}$ and 1B are inter-linked in antiparallel fashion by two hydrogen bonds between N3A and O5B and between N3B and O5A with donor-acceptor distances of 2.840 and $2.957 \AA$, respectively, to form a molecular duplex -(1A-1B)- (Figure 3a and Table 2). The resulting 10-membered ring between $\mathbf{1 A}$ and $\mathbf{1 B}$ is nearly planar. 


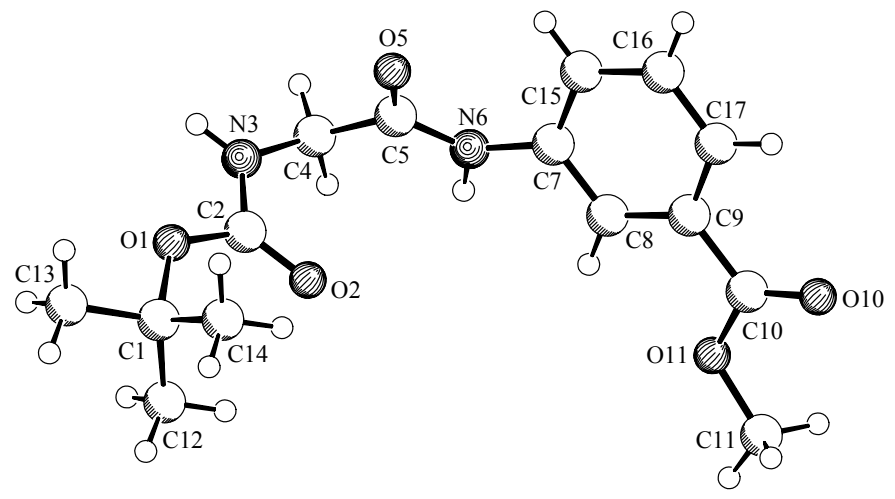

Figure 2. SCHAKAL diagram of pseudopeptide 1 with atom numbering scheme.

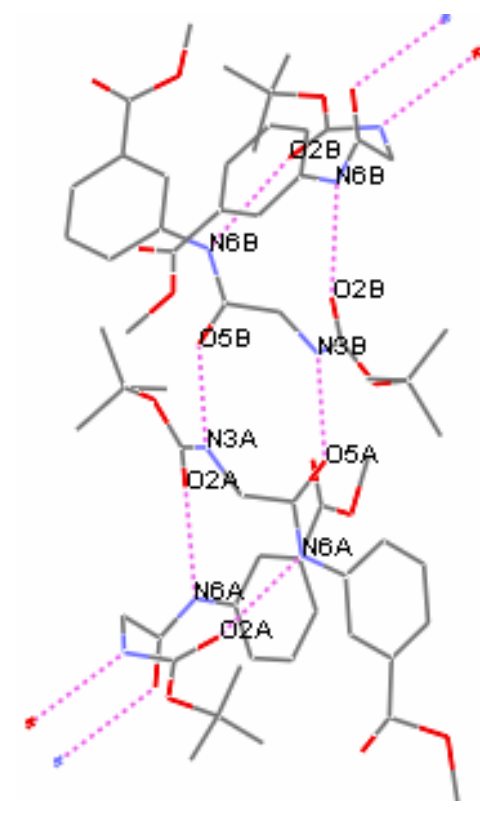

(a)

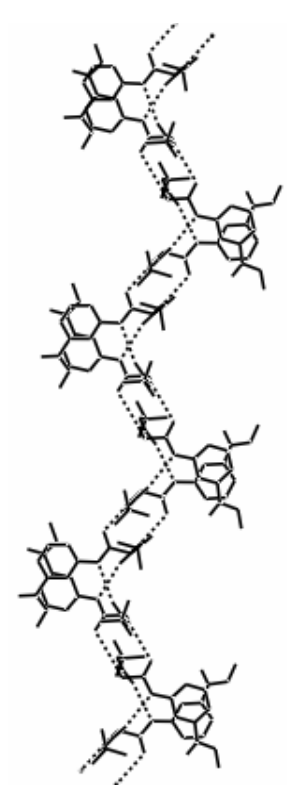

(b)

Figure 3. (a) Showing the packing of $\mathbf{1 A}$ and $\mathbf{1 B}$ through intermolecular hydrogen bonds (hydrogen atoms are omitted); (b) Showing the supramolecular helical assembly along the crystallographic $a$ axis. Intermolecular hydrogen bonds are shown as dotted lines.

In the crystalline state the duplexes -(1A-1B)- are regularly inter-linked via intermolecular hydrogen bonds to form a supramolecular helix along the crystallographic $a$ axis (Figure $3 b$ ). The pattern of self-assembly along the helix axis is found to be -(1A-1B)-(1B-1A)-(1A-1B)-(1B1A)-. Two adjacent 1A molecules are inter-connected in antiparallel fashion by two intermolecular hydrogen bonds between N6A and O2A with a donor-acceptor distance $2.866 \AA$ (Figure 3a, Table 2). Similarly two adjacent 1B molecules are also connected through two intermolecular hydrogen bonds between $\mathrm{N} 6 \mathrm{~B}$ and $\mathrm{O} 2 \mathrm{~B}$ with a donor-acceptor distance of 
$2.896 \AA$ Á. The resulting 14-membered rings between $\mathbf{1 A}$ and $\mathbf{1 A}$ and also between $\mathbf{1 B}$ and $\mathbf{1 B}$ are twisted. This twisted nature of hydrogen bonding incorporates helical sense in the self-assembly to produce supramolecular helical structure. The arrangement is further stabilized by $\pi-\pi$ interactions between the phenyl rings of two adjacent $\mathbf{1 A}$ and two adjacent $1 \mathbf{B}$ molecules (Figure $3 a, b)$. The result shows that the self-assembly of a small pseudopeptide can lead to a complex supramolecular architecture such as helix.

Table 1. Selected back-bone torsion angles (deg) in pseudopeptides 1-3

\begin{tabular}{lrlr}
\hline Mol 1A & & & \\
O1A-C2A-N3A-C4A & $-177.5(1)$ & C5A-N6A-C7A-C8A & $169.5(2)$ \\
C2A-N3A-C4A-C5A $(\varphi)$ & $62.6(2)$ & N6A-C7A-C8A-C9A & $179.7(2)$ \\
N3A-C4A-C5A-N6A $(\psi)$ & $-130.6(2)$ & C7A-C8A-C9A-C10A & $-178.4(1)$ \\
C4A-C5A-N6A-C7A & $179.6(2)$ & C8A-C9A-C10A-O11A & $174.1(2)$ \\
Mol 1B & & & \\
O1B-C2B-N3B-C4B & $-179.6(1)$ & C5B-N6B-C7B-C8B & $143.2(2)$ \\
C2B-N3B-C4B-C5B $(\varphi)$ & $-65.2(2)$ & N6B-C7B-C8B-C9B & $-178.4(2)$ \\
N3B-C4B-C5B-N6B $(\psi)$ & $138.0(2)$ & C7B-C8B-C9B-C10B & $177.8(2)$ \\
C4B-C5B-N6B-C7B & $-176.2(2)$ & C8B-C9B-C10B-O11B & $1.6(2)$ \\
2 & & & \\
O1-C2-N3-C4 & $169.5(2)$ & C5-N6-C7-C8 & $-164.6(2)$ \\
C2-N3-C4-C5 $(\varphi)$ & $76.5(3)$ & N6-C7-C8-C9 & $178.2(2)$ \\
N3-C4-C5-N6 $(\psi)$ & $-171.4(2)$ & C7-C8-C9-C10 & $-177.4(2)$ \\
C4-C5-N6-C7 & $175.0(2)$ & C8-C9-C10-011 & $175.9(2)$ \\
3 & & & \\
N1-C2-C3-N5 & $-175.9(1)$ & C6-C11-C10-C12 & $-177.3(1)$ \\
C2-C3-N5-C6 & $168.9(2)$ & C11-C10-C12-O13 & $-23.6(2)$ \\
C3-N5-C6-C11 & $153.1(2)$ & C11-C10-C12-O14 & $156.1(2)$ \\
N5-C6-C11-C10 & $171.9(1)$ & & \\
\hline
\end{tabular}


Table 2. Intermolecular hydrogen bonding parameters of pseudopeptides 1-3

\begin{tabular}{|c|c|c|c|}
\hline D-H---A & H---A/ Á & D---A/ Á & D-H---A/ ${ }^{o}$ \\
\hline \multicolumn{4}{|l|}{1} \\
\hline N3A-H3A---O5B & 1.98 & 2.840 & 178.8 \\
\hline N6A-H6A---O2A ${ }^{a}$ & 1.99 & 2.866 & 179.0 \\
\hline N3B-H3B---O5A & 2.09 & 2.957 & 169.8 \\
\hline N6B-H6B---O2B ${ }^{b}$ & 1.98 & 2.896 & 174.8 \\
\hline \multicolumn{4}{|l|}{2} \\
\hline N6-H6---O10 ${ }^{c}$ & 2.17 & 3.006 & 171.1 \\
\hline $\mathrm{O} 11-\mathrm{H} 11---\mathrm{O} 2^{d}$ & 1.87 & 2.625 & 150.6 \\
\hline N3-H3---O5 ${ }^{e}$ & 2.08 & 2.921 & 174.7 \\
\hline \multicolumn{4}{|l|}{3} \\
\hline O15-H15A---O14 ${ }^{f}$ & 2.28 & 3.027 & 138.0 \\
\hline O15-H15B---O14 ${ }^{g}$ & 1.74 & 2.705 & 169.1 \\
\hline O15-H15A---O13 & 2.06 & 2.945 & 160.8 \\
\hline N1-H1B---O15 & 1.82 & 2.740 & 167.9 \\
\hline N1-H1C---O14 ${ }^{h}$ & 1.85 & 2.749 & 170.6 \\
\hline N1-H1A---O13 ${ }^{i}$ & 1.79 & 2.726 & 174.7 \\
\hline N5-H5---O4 ${ }^{j}$ & 2.02 & 2.882 & 159.9 \\
\hline
\end{tabular}

Symmetry equivalents: ${ }^{a}-\mathrm{x}+1 / 2,-\mathrm{y}+3 / 2, \mathrm{z} ;{ }^{b}-\mathrm{x}+1 / 2,-\mathrm{y}+1 / 2, \mathrm{z} ;{ }^{c}-\mathrm{x}+1,-\mathrm{y}+1,-\mathrm{z}+1$; ${ }^{d}-\mathrm{x}+1,-\mathrm{y},-\mathrm{z}+1{ }^{e}-\mathrm{x}+1 / 2, \mathrm{y}+1 / 2,-\mathrm{z}+1 / 2 ;^{f} \mathrm{x}+1,-\mathrm{y}+1 / 2, \mathrm{z}-1 / 2{ }^{g}-\mathrm{x}+1,-\mathrm{y},-\mathrm{z}$; ${ }^{h} \mathrm{x},-\mathrm{y}+1 / 2, \mathrm{z}-1 / 2 ;{ }^{i}-\mathrm{x}+1,-\mathrm{y}+1,-\mathrm{z} ;{ }^{j} \mathrm{x}-1, \mathrm{y}, \mathrm{z}$.

The hydrolysis of the methyl ester group at the C-terminus of peptide 1 affords peptide 2 (Figure 4). The single crystals of $\mathbf{2}$ are grown from ethyl acetate by slow evaporation. Peptide 2 crystallizes with one molecule in the asymmetric unit. The $\phi, \psi$ values at Gly $\left(76.6^{\circ},-171.4^{\circ}\right)$ and the backbone torsion angles at $m$-ABA indicate an extended structure in peptide 2 (Table 1, Figure 4). Due to the presence of free $-\mathrm{CO}_{2} \mathrm{H}$ at the $\mathrm{C}$-terminus, peptide 2 shows a remarkable change in the self-assembly compared to peptide 1 . Two molecules of peptide 2 are inter-linked in antiparallel fashion through intermolecular hydrogen bonds between $\mathrm{N} 6-\mathrm{H}----\mathrm{O}(10)=\mathrm{C}$ to form molecular duplex (Figure 5a, Table 2). The duplexes are further inter-connected through hydrogen bonds between Boc $\mathrm{C}=\mathrm{O}(2)$ and carboxylic H11-O11 to form supramolecular staircase running infinitely in the same direction (Figure $5 \mathrm{~b}$ and Table 2). The formation of metal ion directed supramolecular straicase ${ }^{14}$ and nanostaircase through self-assembly of conformationally rigid molecular scaffolds have been reported recently. ${ }^{15}$ The present result shows that not only rigid molecular scaffolds but also flexible molecule like 2 can form supramolecular straicase through self-assembly. 


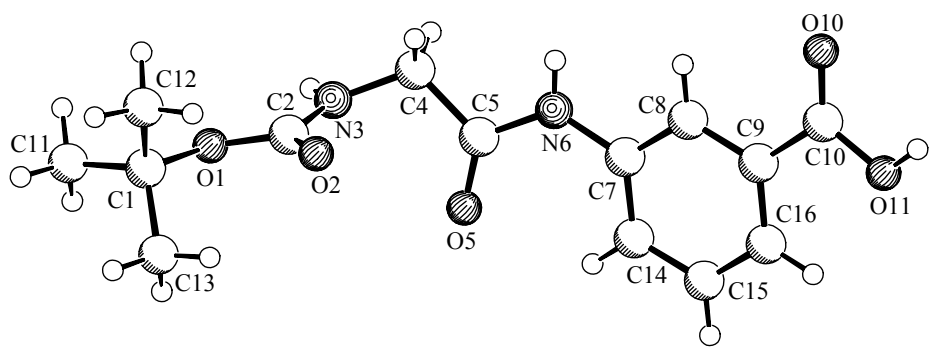

Figure 4. SCHAKAL diagram of pseudopeptide 2 with atom numbering scheme.

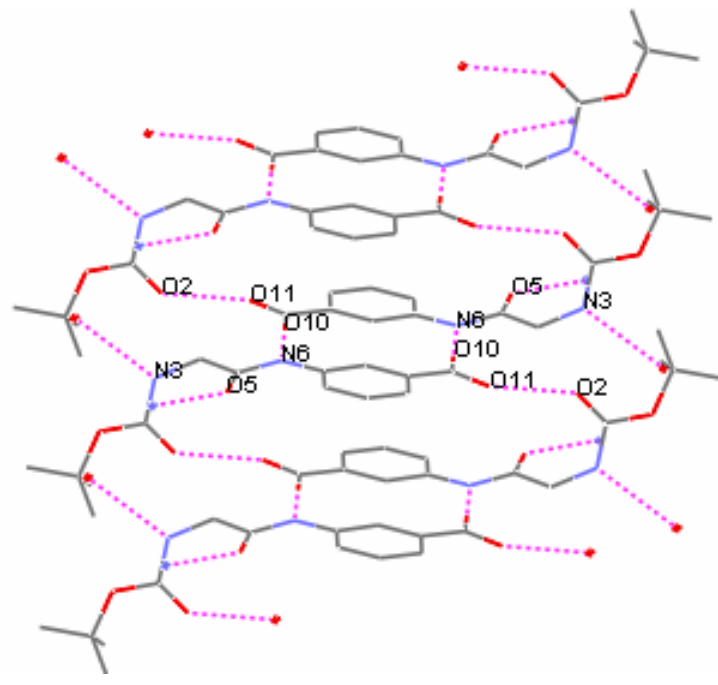

(a)

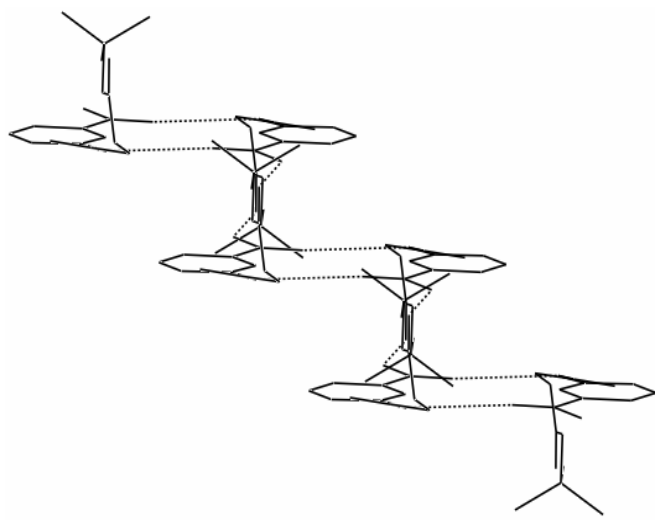

(b)

Figure 5. (a) Crystal packing of 2 illustrating the formation of supramolecular staircase (hydrogen atoms are omitted); (b) A lateral view of the same supramolecular staircase structure. Intermolecular hydrogen bonds are shown as dotted lines.

The removal of Boc group from the N-terminus of peptide 2 by acid catalysis produces water soluble peptide $\mathbf{3}$. The colorless monoclinic crystals of peptide $\mathbf{3}$ are obtained from water by slow evaporation. In the solid state the peptide remains in the zwitterionic form (Figure 6). The backbone torsion angles of 3, that characterize an extended conformation, include N1-C2-C3-N5 $=-175.9^{\circ}, \mathrm{C} 2-\mathrm{C} 3-\mathrm{N} 5-\mathrm{C} 6=168.9^{\circ}, \mathrm{C} 3-\mathrm{N} 5-\mathrm{C} 6-\mathrm{C} 11=153.1^{\circ}, \mathrm{N} 5-\mathrm{C} 6-\mathrm{C} 11-\mathrm{C} 10=171.9^{\circ}, \mathrm{C} 6-$ $\mathrm{C} 11-\mathrm{C} 10-\mathrm{C} 12=-177.3^{\circ}$ and $\mathrm{C} 11-\mathrm{C} 10-\mathrm{C} 12-\mathrm{O} 14=156.1^{\circ}$ (Figure 6 and Table 1). The incorporation of $m$-ABA helps to attain a fully extended conformation, which is necessary for $\beta$ sheet formation.

In the crystalline state peptide $\mathbf{3}$ are inter-linked in head-to-tail fashion along the crystallographic $a$ axis through intermolecular hydrogen bonds N1-H1C---O14 between $-\mathrm{CO}_{2}{ }^{-}$ and $\mathrm{H}_{3}{ }^{+} \mathrm{N}$ - (Figure 7, Table 2). The arrays of molecules are further inter-linked along the crystallographic $b$ axis to form layers of peptides stabilized by the hydrogen bond between $\mathrm{O} 4$ and N5 with a donor-acceptor distance of $2.882 \AA$ (Figure 7, Table 2). The arrangement is 
further stabilized by $\pi-\pi$ interactions between the phenyl rings and water mediated hydrogen bonds O15-H15A--O14, O15-H15A--O13 and N1-H1B--O15 between $-\mathrm{CO}_{2}{ }^{-}$and $\mathrm{H}_{3}{ }^{+} \mathrm{N}$ - (Figure 7, Table 2). Several such layers are cross-linked along the crystallographic $\boldsymbol{c}$ axis through water mediated hydrogen bond O15-H15B--O14 and direct hydrogen bonds N1-H1A--O13 between $\mathrm{CO}_{2}{ }^{-}$and $\mathrm{H}_{3}{ }^{+} \mathrm{N}$ - to form supramolecular $\beta$-sheet structure (Figure 8, Table 2). It is well documented that $\pi-\pi$ interactions ${ }^{16}$ and $\beta$-sheet cross-linking ${ }^{17}$ play significant roles in amyloid fibril formation. Supramolecular $\beta$-sheets also have many potential applications in material ${ }^{18}$ as well as in biological sciences. ${ }^{19}$

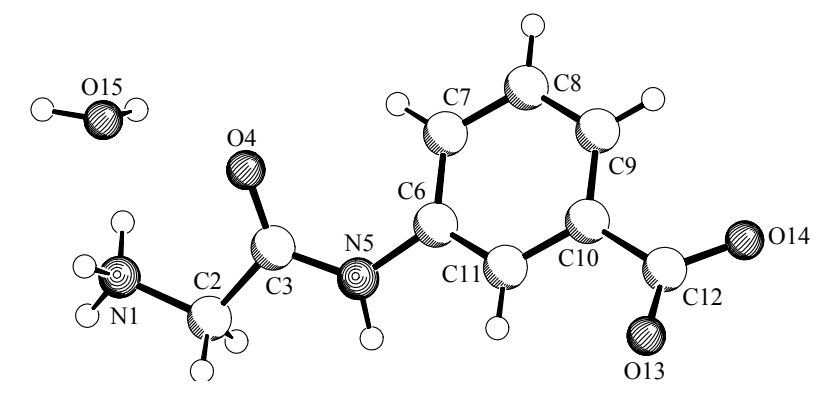

Figure 6. SCHAKAL diagrams of pseudopeptide 3 with atom numbering scheme.

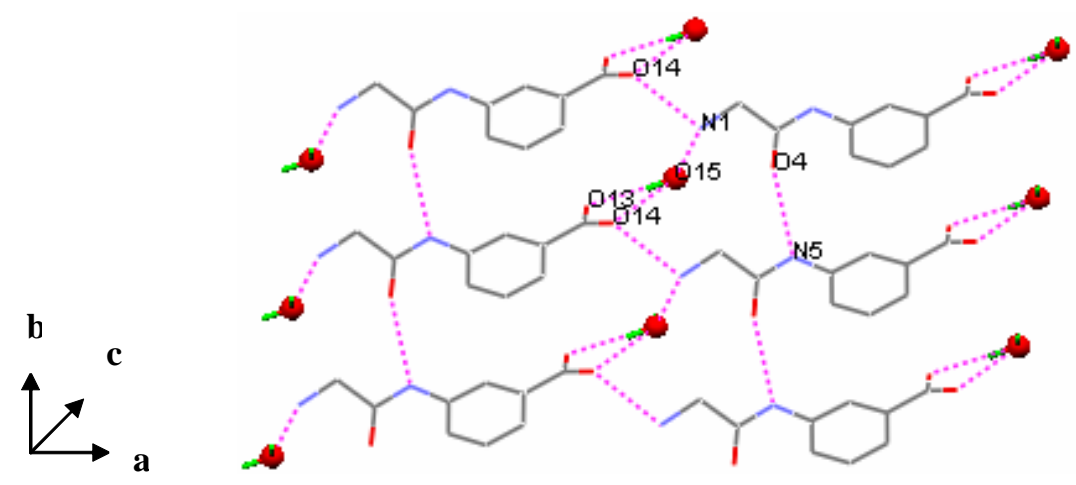

Figure 7. Packing diagram of 3 shows the formation layer of pseudopeptides along the crystallographic $\boldsymbol{b}$ axis. 


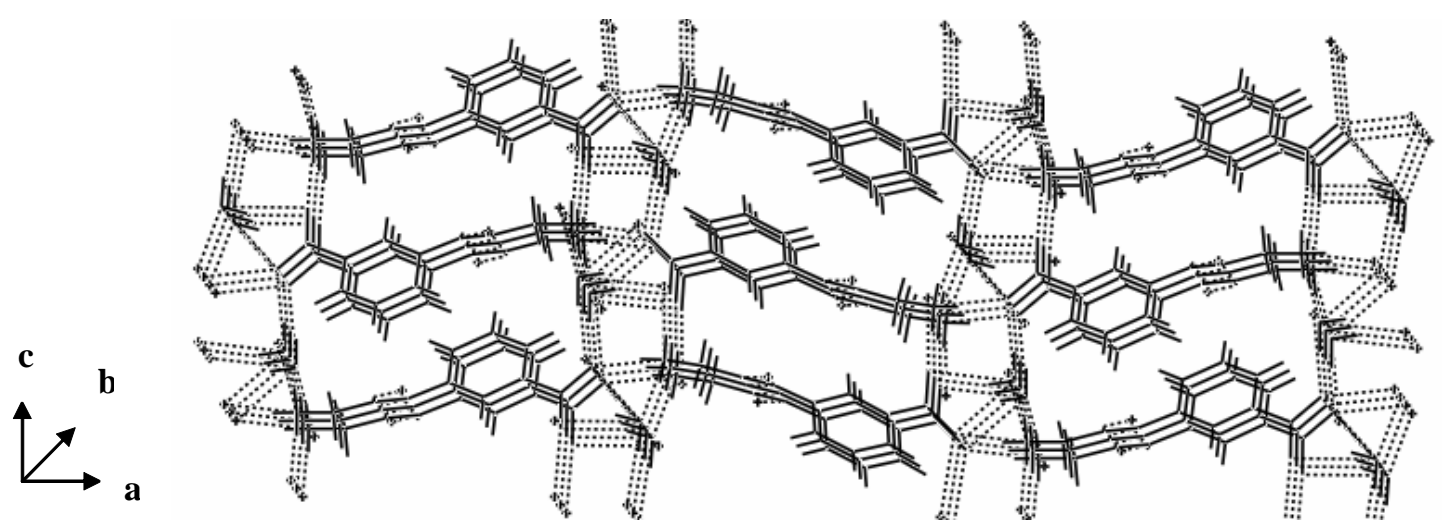

Figure 8. Showing the cross-linking between the pseudopeptide $\mathbf{3}$ layers along the crystallographic $c$ axis to form supramolecular $\beta$-sheet through higher order self-assembly.

\section{Conclusions}

The present study shows that the terminally modified pseudopeptide Gly-m-ABA generates various kinds of building blocks that can self-assemble to different types of supramolecular architectures such as helix, $\beta$-sheet and staircase. The protection and deprotection of the $\mathrm{N}$ - and C-terminal groups of the pseudopeptide influence the pattern of self-assembly significantly. The gradual removal of protecting groups from 1 to $\mathbf{3}$ produces more number of donor and acceptor groups which can participate in fabricating supramolecular structures through hydrogen bond mediated self-assembly. The study provides valuable insights for engineering supramolecular architectures in crystal.

\section{Experimental Section}

Synthesis of peptides. The peptides 1-3 were synthesized by conventional solution phase methods. ${ }^{20}$ The Boc group was used for N-terminal protection, and the C-terminus was protected as a methyl ester. Deprotection of $\mathrm{N}$ - and $\mathrm{C}$-terminus were performed by using $\mathrm{CF}_{3} \mathrm{COOH}$ and saponification, respectively. Couplings were mediated by dicyclohexylcarbodiimide (DCC). All peptides were characterized by thin layer chromatography on silica gel and purified by column chromatography using silica gel (100-200 mesh) as the stationary phase. The reported peptides 13 were fully characterized by X-ray crystallography, NMR and IR spectroscopy.

Peptide Boc-Gly-m-ABA-OMe (1). Boc-Gly-OH (2.0 g, $11.4 \mathrm{mmol})$ was dissolved in dichloromethane (DCM, $10 \mathrm{ml}$ ) in an ice-water bath. $m$-ABA-OMe obtained from its hydrochloride $^{13,14}$ (4.3 g, $\left.22.9 \mathrm{mmol}\right)$ was added to it, followed by DCC (3.5 g, 17.2 mmol). The reaction mixture was stirred at room temperature for 1 day. The precipitated dicyclohexylurea 
(DCU) was filtered. The organic layer was washed with $1 \mathrm{M} \mathrm{HCl}(3 \times 30 \mathrm{~mL}), 1 \mathrm{M} \mathrm{Na}_{2} \mathrm{CO}_{3}$ solution $(3 \times 30 \mathrm{~mL})$ and water. The solvent was then dried over anhydrous $\mathrm{Na}_{2} \mathrm{SO}_{4}$ and evaporated in vacuo, giving a light yellow gum. Yield: $3.2 \mathrm{~g}(90.9 \%)$. Purification was done using silica gel as stationary phase and ethyl acetate-petroleum ether mixture as the eluent. Single crystals were grown from chloroform-petroleum ether mixture by slow evaporation and were stable at room temp. $\mathrm{Mp}=105-107^{\circ} \mathrm{C}$; Elemental analysis calcd for $\mathrm{C}_{15} \mathrm{H}_{20} \mathrm{~N}_{2} \mathrm{O}_{5}(308.33)$ : C, 58.43; H, 6.54; N, 9.09 \%; Found: C, 58.37; H, 6.62; N, 9.15 \%. IR (KBr): 3306, 2978, 1727 , $1674,1612,1556,1490,1430,1298,1238,1203,1165 \mathrm{~cm}^{-1} .{ }^{1} \mathrm{H}$ NMR $300 \mathrm{MHz}\left(\mathrm{CDCl}_{3}\right.$, $\delta$ ppm): 8.89 (m-ABA-NH, 1H, s), 8.06 [Ha (m-ABA), 1H, $s], 7.82$ [Hd $(m-\mathrm{ABA}), 1 \mathrm{H}, d, J=7.8$ $\mathrm{Hz}$, 7.73 [Hb (m-ABA), 1H, $d, J=7.8 \mathrm{~Hz}$ ], 7.33 [Hc $(m-\mathrm{ABA}), 1 \mathrm{H}, t, J=8.1 \mathrm{~Hz}$ ], 5.69 (Gly$\mathrm{NH}, 1 \mathrm{H}, t, J=5.2 \mathrm{~Hz}), 3.99\left(\mathrm{C}^{\alpha} \mathrm{Hs}\right.$ of Gly, $\left.2 \mathrm{H}, d, J=5.2 \mathrm{~Hz}\right), 3.86\left(-\mathrm{OCH}_{3}, 3 \mathrm{H}, s\right), 1.44\left(\mathrm{CH}_{3} \mathrm{~s}\right.$ Boc, $9 \mathrm{H}, s) ;{ }^{13} \mathrm{C} \mathrm{NMR} 75 \mathrm{MHz}\left(\mathrm{CDCl}_{3}, \delta \mathrm{ppm}\right): 168.3,166.7,156.5,137.8,130.7,129.0,125.4$, $124.5,120.9,80.5,52.2,45.2,28.3$.

Peptide Boc-Gly-m-ABA-OH (2). Peptide 1 (3.2 g, $10.4 \mathrm{mmol}$ ) was dissolved in methanol $(25 \mathrm{~mL})$ and $2 \mathrm{M} \mathrm{NaOH}(7 \mathrm{~mL})$ was added to it. The reaction mixture was stirred for $24 \mathrm{hr}$ at room temperature. The progress of the reaction was monitored by TLC. After completion of the reaction methanol was evaporated. The residue was dissolved in water and washed with diethyl ether. The aqueous layer was cooled in ice-bath, neutralized with $2 \mathrm{M} \mathrm{HCl}$ and extracted with ethyl acetate. The solvent was evaporated in vacuo to give a white solid. Yield: $2.75 \mathrm{~g}$ (90.1\%). Purification was done using silica gel as stationary phase and ethyl acetate-petroleum ether mixture as the eluent. Single crystals were grown from ethyl acetate by slow evaporation and were stable at room temp. $\mathrm{Mp}=195-197^{\circ} \mathrm{C}$; Elemental analysis calcd for $\mathrm{C}_{14} \mathrm{H}_{18} \mathrm{~N}_{2} \mathrm{O}_{5}(294.30)$ : C, 57.13; H, 6.16; N, 9.53 \%; Found: C, 57.21; H, 6.23; N, $9.61 \%$. IR (KBr): 3319, 3059, 2975, 2927, 1690, 1666, 1548, 1482, 1422, 1373, 1299, 1248, $1153 \mathrm{~cm}^{-1} .{ }^{1} \mathrm{H}$ NMR $300 \mathrm{MHz}$ (DMSO$\left.\mathrm{d}_{6}, \delta \mathrm{ppm}\right): 10.12$ (m-ABA-NH, 1H,s), 8.22 [Ha (m-ABA), 1H, s], 7.76 [Hd (m-ABA), 1H, $d, J$ $=7.7 \mathrm{~Hz}], 7.62[\mathrm{Hb}(m-\mathrm{ABA}), 1 \mathrm{H}, d, J=7.7 \mathrm{~Hz}], 7.42[\mathrm{Hc}(m-\mathrm{ABA}), 1 \mathrm{H}, t, J=8.1 \mathrm{~Hz}], 7.01$ (Gly-NH, 1H, $t$ ), 4.00 (C ${ }^{\alpha} \mathrm{Hs}$ of Gly, 2H, $\left.d, J=5.4 \mathrm{~Hz}\right), 1.38\left(\mathrm{CH}_{3} \mathrm{~s}\right.$ Boc, $\left.9 \mathrm{H}, s\right) .{ }^{13} \mathrm{C}$ NMR 75 MHz (DMSO-d 6 , $\delta$ ppm): 169.1, 167.7, 156.5, 139.5, 131.7, 129.5, 124.6, 123.8, 120.4, 78.8, 44.2, 28.6.

Peptide $^{+} \mathbf{N H}_{3}$-Gly-m-ABA-CO${ }_{2}^{-}$(3). Peptide 2 (2.75 g, $\left.9.4 \mathrm{mmol}\right)$ was dissolved in trifluoroacetic acid $(6 \mathrm{~mL})$ at $0^{\circ} \mathrm{C}$. Then the reaction mixture was stirred at room temperature and the progress of deprotection was monitored by TLC. After $6 \mathrm{hr}$ of stirring trifluoroacetic acid was removed under vacuo and the residue was taken in $15 \mathrm{ml}$ of distilled water, washed with diethyl ether $(2 \times 15 \mathrm{ml})$. The aqueous part was then dried under vacuo to yield white solid. Yield: $1.5 \mathrm{~g}(82.6 \%)$. Purification was done using silica gel as stationary phase and chloroformmethanol mixture as the eluent. Single crystals were grown from water by slow evaporation and were stable at room temp. $\mathrm{Mp}=231-233^{\circ} \mathrm{C}$. Elemental analysis calcd for $\mathrm{C}_{9} \mathrm{H}_{10} \mathrm{~N}_{2} \mathrm{O}_{2} \cdot \mathrm{H}_{2} \mathrm{O}$ (212.20): C, 50.94; H, 5.70; N, $13.20 \%$; Found: C, 50.86; H, 5.64; N, $13.15 \%$. IR (KBr): 3401, 3286, 2921, 2670, 2370, 1675, 1544, 1383, 1298, $1119 \mathrm{~cm}^{-1} .{ }^{1} \mathrm{H}$ NMR $300 \mathrm{MHz}$ (DMSO$\left.\mathrm{d}_{6}, \delta \mathrm{ppm}\right): 10.70(m-\mathrm{ABA}-\mathrm{NH}, 1 \mathrm{H}, s), 8.26$ [Ha (m-ABA), 1H, s], 7.78 [Hd (m-ABA), 1H, $d, J$ 
$=7.8 \mathrm{~Hz}$ ], $7.67[\mathrm{Hb}(m-\mathrm{ABA}), 1 \mathrm{H}, d, J=7.8 \mathrm{~Hz}], 7.47$ [Hc $(m-\mathrm{ABA}), 1 \mathrm{H}, t, J=8.1 \mathrm{~Hz}], 4.00$ $\left(\mathrm{C}^{\alpha} \mathrm{Hs}\right.$ of Gly, 2H, br. $\left.s\right) .{ }^{13} \mathrm{C}$ NMR $75 \mathrm{MHz}\left(\right.$ DMSO-d $\left._{6}, \delta \mathrm{ppm}\right): 167.5,165.5,138.8,132.1$, 129.7, 125.2, 123.8, 120.4, 41.5 .

\section{Single crystal $X$-ray diffraction study}

Data sets were collected with Nonius KappaCCD diffractometers using Mo-radiation equipped with a rotating anode generator (Table 3). Programs used: data collection COLLECT, ${ }^{21}$ data reduction Denzo-SMN, ${ }^{22}$ absorption correction SORTAV ${ }^{23}$ and Denzo, ${ }^{24}$ structure solution SHELXS-97, ${ }^{25}$ structure refinement SHELXL-97, ${ }^{26}$ graphics SCHAKAL. ${ }^{27}$

CCDC 658984(1), 658985(2), and 658986(3) contain the supplementary crystallographic data for this paper. These data can be obtained free of charge at www.ccdc.cam.ac.uk/conts/retrieving.html [or from the Cambridge Crystallographic Data Centre, 12 Union Road, Cambridge CB2 1EZ, UK; fax: (internet.) +44(1223)336-033, E-mail: deposit@ccdc.cam.ac.uk].

Table 3. Crystallographic data for pseudopeptides 1-3

\begin{tabular}{|c|c|c|c|}
\hline & 1 & 2 & 3 \\
\hline Formula & $\mathrm{C}_{15} \mathrm{H}_{20} \mathrm{~N}_{2} \mathrm{O}_{5}$ & $\mathrm{C}_{14} \mathrm{H}_{18} \mathrm{~N}_{2} \mathrm{O}_{5}$ & $\mathrm{C}_{9} \mathrm{H}_{10} \mathrm{~N}_{2} \mathrm{O}_{3} * \mathrm{H}_{2} \mathrm{O}$ \\
\hline Formula weight & 308.33 & 294.30 & 212.21 \\
\hline Crystallising solvent & Chloroform & Ethyl acetate & Water \\
\hline Crystal colour & Colourless & Colourless & Colourless \\
\hline Crystal system & Orthorhombic & Monoclinic & Monoclinic \\
\hline Space group & $P c c n$ & $C 2 / \mathrm{c}$ & $P 2_{1} / \mathrm{c}$ \\
\hline $\mathrm{a}(\AA)$ & $20.0442(3)$ & $28.4205(6)$ & $4.7455(1)$ \\
\hline $\mathrm{b}(\AA)$ & $16.8270(2)$ & $5.4632(1)$ & $8.9043(1)$ \\
\hline c $(\AA)$ & $20.0430(2)$ & $20.6704(5)$ & $23.0044(1)$ \\
\hline$\alpha\left(^{0}\right)$ & 90.000 & 90.000 & 90.000 \\
\hline$\beta\left(^{0}\right)$ & 90.000 & $115.767(2)$ & $94.551(1)$ \\
\hline$\gamma\left(\left(^{0}\right)\right.$ & 90.000 & 90.000 & 90.000 \\
\hline Z & 16 & 8 & 4 \\
\hline $\mathrm{V}\left(\AA^{3}\right)$ & $6760.18(15)$ & $2890.31(11)$ & $968.99(2)$ \\
\hline Temperature $\left({ }^{0} \mathrm{C}\right)$ & -75 & -50 & -50 \\
\hline$\mu\left(\mathrm{cm}^{-1}\right)$ & 9.20 & 8.68 & 9.82 \\
\hline $\mathrm{D}_{\text {calculated }}\left(\mathrm{g} \mathrm{cm}^{-3}\right)$ & 1.212 & 1.353 & 1.455 \\
\hline R (int) & 0.070 & 0.073 & 0.052 \\
\hline No of independent reflections & 8060 & 2514 & 1744 \\
\hline Reflections with $\mathrm{I}>2 \sigma(\mathrm{I})$ & 4324 & 1912 & 1646 \\
\hline $\mathrm{R}_{1}(\mathrm{I}>2 \sigma(\mathrm{I}))$ & 0.051 & 0.049 & 0.049 \\
\hline$w \mathrm{R}_{2}(\mathrm{I}>2 \sigma(\mathrm{I}))$ & 0.124 & 0.109 & 0.137 \\
\hline
\end{tabular}




\section{Acknowledgements}

A.D. and S. K. thank CSIR, New Delhi, India, for providing a senior research fellowship. P. K. thanks UGC, New Delhi for providing Project Fellowship. The financial assistance of UGC, New Delhi is acknowledged [Major Research Project, No.32-190/2006 (SR)].

\section{References and Notes}

1. (a) Mann, S. Biomineralization: Principles and Concepts in Bioinorganic Materials Chemistry; Oxford University Press: Oxford, 2001. (b) Vincent J. F.; Currey, J. D. The Mechanical Properties of Biological Materials; Eds.; Cambridge University Press: Cambridge, 1980.

2. Vincent J. F.; Currey, J. D. The Mechanical Properties of Biological Materials; Eds; Cambridge University Press: Cambridge, 1980.

3. Franklin, R. E. Nature 1955, 175, 379.

4. Ramachandran, G. N.; Kartha, G. Nature 1955, 176, 593.

5. Watson, J. D.; Crick, F. C. H. Nature 1953, 171, 737.

6. (a) Haldar, D.; Drew, M. G. B.; Banerjee, A. Tetrahedron 2006, 62, 6370. (b) Das, A. K.; Banerjee, A.; Drew, M. G. B.; Ray, S.; Haldar, D.; Banerjee, A. Tetrahedron 2005, 61, 5027. (c) Görbitz, C. H. Chem.-Eur. J. 2007, 13, 1022. (d) Guha, S.; Drew, M. G. B.; Banerjee, A. Org. Lett. 2007, 9, 1347. (e) Parthasarathy, R.; Chaturvedi, S.; Go, K. Proc. Natl. Acad. Sci. USA 1990, 87, 871. (f) Guha, S.; Drew, M. G. B.; Banerjee, A. Tetrahedron Lett. 2006, 47, 7951.

7. (a) Dutt, A.; Drew, M. G. B.; Pramanik, A. Org. Biomol. Chem. 2005, 3, 2250. (b) Kundu, S. K.; Mazumdar, P. A.; Das, A. K.; Bertolasi, V.; Pramanik, A. J. Chem. Soc. Perkin Trans. 2 2002, 1602. (c) Maji, S. K.; Haldar, D.; Drew, M. G. B.; Banerjee, A.; Das, A. K.; Banerjee, A. Tetrahedron 2004, 60, 3251. (d) Banerjee, A.; Das, A. K.; Drew, M. G. B.; Banerjee, A. Tetrahedron 2005, 61, 5906. (e) Ray, S.; Das, A. K.; Drew, M. G. B.; Banerjee, A. Chem. Commun. 2006, 40, 4230. (f) Ray, S.; Drew, M. G. B.; Das, A. K.; Banerjee, A. Supramolecular Chemistry 2006, 18, 455.

8. (a) Taubes, G.; Science 1996, 271, 1493. (b) Lansbury, P. T. Jr. Acc. Chem. Res. 1996, 29, 317. (c) Rochet, J. C.; Lansbury, P. T. Jr. Curr. Opin. Struct. Biol. 2000, 10, 60.

9. (a) Goedert, M.; Spillntini, M. G.; Davies, S. W. Curr. Opin. Neurobiol. 1998, 8, 619. (b) Spillantini, M. G.; Crowther, R. A.; Jakes, R.; Hasegawa, M.; Goedert, M. Proc. Natl. Acad. Sci. U.S.A. 1998, 95, 6469.

10. (a) Pan, K. M.; Baldwin, M.; Nguyen, J.; Gasset, M.; Serban, A.; Groth, D.; Mehlhorn, I.; Huang, Z.; Fletterick, R. J.; Cohen, F. E. Proc. Natl. Acad. Sci. U.S.A. 1993, 90, 10962. (b) Prusiner, S. B. Proc. Natl. Acad. Sci. U.S.A. 1998, 95, 13363. 
11. (a) Reches, M.; Gazit, E. Nano Lett. 2004, 4, 581. (b) Ghadiri, M. R.; Granja, J. R.; Buehler, L. K. Nature 1994, 369, 301. (c) Guha, S.; Drew, M. G. B.; Banerjee, A. Chem. Mater. 2008 , 20, 2282. (d) Ray, S.; Drew, M. G. B.; Das, A. K.; Banerjee, A. Tetrahedron 2006, 62, 7274.

12. Haldar, D.; Banerjee, A.; Drew, M. G. B.; Das, A. K.; Banerjee, A. Chem. Commun. 2003, 1406.

13. Reches, M.; Gazit, E. Science 2003, 300, 625.

14. (a) Ghosh, S, K.; Bharadwaj, P. K. Eur. J. Inorg. Chem. 2005, 4886. (b) Gabbai, F. P.; Schier, A.; Riede, J. Angew. Chem., Int. Ed. 1998, 37, 622. (c) Fortin, D; Drouin, M.; Harvey, P. D. J. Am. Chem. Soc. 1998, 120, 5351. (d) Nagata, N.; Kugimiya, S.; Fujiwara, E.; Kobuke, Y. New J. Chem. 2003, 27, 743. (e) Ren, C, -X.; Zhu, H, -L.; Yang, G.; Chen, X. -M. J. Chem. Soc.; Dalton Trans. 2001, 85. (f) Alexakis, A.; Tomassini, A.; Chouillet, C.; Roland, S.; Mangeney, P.; Bernardinelli, G. Angew. Chem., Int. Ed. 2000, 39, 4093.

15. Ray, S.; Hegde, R. P.; Das, A. K.; Shamala, N.; Banerjee, A. Tetrahedron 2006, 62, 9603.

16. Gazit, E. FASEB J. 2002, 16, 77.

17. (a) Makin O. S.; Serpell, L. C. J. Mol. Biol. 2004, 335, 1279. (b) Bond, J. P.; Deverin, S. P.; Inouye, H.; El-Agnaf, O. M. A.; Teeter, M. M.; Krischner, D. A. J. Struc. Biol. 2003, 141, 156. (c) Sundae, M.; Serpell, L. C.; Bartlam, M.; Fraser, P. E.; Pepys, M. B.; Blake, C. C. J. Mol. Biol. 1997, 273, 729. (d) Sundae, M.; Blake, C. Adv. Protein. Chem. 1997, 50, 123. (e) Damas, A. M.; Saraiva, M. J. J. Struc. Biol. 2000, 130, 290.

18. (a) Rathore, O.; Sogah, D. Y. J. Am. Chem. Soc. 2001, 123, 5231. (b) Krejchi, M. T.; Atkins, E. D.T.; Waddon, A. J.; Fournier, M. J.; Mason, T. L.; Tirrell, D. A. Science 1994, 265 , 1427. (c) Caplan, M. R.; Moore, P. N.; Zhang, S.; Kamm, R. D.; Lauffenburger, D. A. Biomacromolecules 2000, 1, 627. (d) Vauthey, S.; Santoso, S.; Gong, H.; Watson, N.; Zhang, S. Proc. Natl. Acad. Sci. USA 2002, 99, 5355.

19. (a) Antzutkin, O. N.; Balbach, J. J.; Leapman, R. D.; Rizzo, N. W.; Reed, J.; Tycko, R. Proc. Natl. Acad. Sci. USA 2000, 97, 13045. (b) Tjernberg, L. O.; Callaway, D. J. E.; Tjernberg, A.; Hahne, S.; Lilliehook, C.; Terenius, L.; Thyberg, J.; Nordstedt, C. J. Biol. Chem. 1999, 274, 12619. (c) Benzinger, T. L. S.; Gregory, D. M.; Burkoth, T. S.; Miller-Auer, H.; Lynn, D. G.; Botto, R. E.; Meredith, S. C. Proc. Natl. Acad. Sci. USA 1998, 95, 13407. (d) Wang, W.; Hecht, M. H. Proc. Natl. Acad. Sci. USA 2002, 99, 2760.

20. Bodanszky, M.; Bodanszky, A. The Practice of Peptide Synthesis; Springer-Verlag: New York, 1984; pp 1-282.

21. Hooft, R. Collect - Data Collection Software, 1998, Nonius B.V., The Netherlands.

22. Otwinowski, Z.; Minor, W. Methods in Enzymology 1997, 276, 307.

23. (a) Blessing, R. H. Acta Cryst. 1995, A51, 33. (b) Blessing, R. H. J. Appl. Cryst. 1997, 30, 421.

24. Otwinowski, Z.; Borek, D.; Majewski, W.; Minor, W. Acta Cryst. 2003, A59, 228.

25. Sheldrick, G. M. Acta Cryst. 1990, A46, 467.

26. Sheldrick, G. M. Acta Cryst. 2008, A64, 112. 
27. Keller, E. SCHAKAL - A computer program for the graphic representation of molecular and crystallographic models, 1997, University Freiburg, Germany. 